\section{Solubility Constants of Hydroxyl Sodalite at Elevated Temperatures Evaluated from Hydrothermal Experiments: Applications to Nuclear Waste Isolation}

8

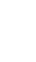

\author{
Yongliang Xiong* \\ Sandia National Laboratories \\ Carlsbad Programs Group \\ 4100 National Parks Highway \\ Carlsbad, New Mexico 88220, USA
}




\section{Abstract}

In this study, solubility constants of hydroxyl sodalite (ideal formula,

$38 \mathrm{Na}_{8}\left[\mathrm{Al}_{6} \mathrm{Si}_{6} \mathrm{O}_{24}\right][\mathrm{OH}]_{2} \cdot 3 \mathrm{H}_{2} \mathrm{O}$ )from $25^{\circ} \mathrm{C}$ to $100^{\circ} \mathrm{C}$ are obtained by applying a high

39 temperature Al-Si Pitzer model to evaluate solubility data on hydroxyl sodalite in high

40 ionic strength solutions at elevated temperatures. A validation test comparing model-

41 independent experimental data to model predictions demonstrates that the solubility

42 values produced by the model are in excellent agreement with the experimental data.

43 The equilibrium constants obtained in this study have a wide range of

44 applications, including synthesis of hydroxyl sodalite, de-silication in the Bayer process

45 for extraction of alumina, and the performance of proposed sodalite waste forms in

46 geological repositories in various lithologies including salt formations. The

47 thermodynamic calculations based on the equilibrium constants obtained in this work

48 indicate that the solubility products in terms of $m_{\Sigma A l} \times m_{\Sigma S i}$ for hydroxyl sodalite are very

49 low (e.g., $\sim 10^{-13}\left[\mathrm{~mol} \bullet \mathrm{kg}^{-1}\right]^{2}$ at $100^{\circ} \mathrm{C}$ ) in brines characteristic of salt formations,

50 implying that sodalite waste forms would perform very well in repositories located in

51 salt. The information regarding the solubility behavior of hydroxyl sodalite obtained in

52 this study provides guidance to investigate the performance of other pure end-members of

53 sodalite such as chloride- and iodide- sodalite, which may be of interest for geological

54 repositories in various media. 


\section{Introduction}

Sodalite, with a chemical formula of $\mathrm{Na}_{8}\left[\mathrm{Al}_{6} \mathrm{Si}_{6} \mathrm{O}_{24}\right][\mathrm{Cl}, \mathrm{OH},]_{2} \bullet \mathrm{xH}_{2} \mathrm{O}$, is one of

60 the important minerals that precipites during the Bayer process in production of alumina

61 when bauxite ores are reacted with caustic liquor. The flexible structure of this mineral

62 allows for immobilization of elements of concern. While $\mathrm{Na}$ bearing compounds are

63 normally very soluble (Vance and Adl, 1981), sodalite-type compounds including

64 hydroxyl sodalite have relatively low solubilities among the variety of $\mathrm{Na}$ compounds.

65 As hydroxyl sodalite can be easily made at relatively low cost, it appears to be poised as a

66 lower-cost alternative for immobilization of radionuclides when compared to other

67 alternatives like vitrification. For example, radioactive iodine $\left({ }^{129} \mathrm{I}\right)$ which has a half-life

68 of 15.7 million years can potentially be immobilized in a sodalite waste form. Also, for

69 contaminated electrolytes produced when electrorefining spent nuclear fuel (e.g.,

70 Sheppard et al., 2006; Hirabayashi et al., 2012; Lepry et al., 2013; Capone et al., 2014;

71 Maddrell et al., 2014; Gilbert, 2013, 2015), sodalite is a candidate waste form. The

72 reprocessing of spent nuclear fuel for disposition using an electrometallurgical method

73 results in a high-level waste salt with chloride (Priebe and Bateman, 2006, 2008). Zeolite

74 is added to the salt waste which is converted to sodalite at high temperatures $\left(\sim 900^{\circ} \mathrm{C}\right)$

75 (Priebe and Bateman, 2006, 2008). Finally, disposal of sodium from desalination plants

76 is also a huge issue. Since hydroxyl sodalite can be made from the materials considered

77 as industrial wastes such as fly ash and paper-sludge ash (e.g., Zeng et al., 2002; Wajima

78 et al., 2007), hydroxyl sodalite can also be considered to be a viable alternative for

79 disposal of sodium from desalination plants. 
81 a candidate waste form for the waste generated by the $\mathrm{LiCl}-\mathrm{Li}_{2} \mathrm{O}$ oxide reduction (Park et

82 al., 2013) electrochemical process of spent nuclear fuel (UNF) (Lepry et al., 2013):

83

93 (Morss et al., 2000). In most cases, the anion structural site in sodalite would be

94 occupied by the nuclides of interest such as $\mathrm{TcO}_{4}{ }^{-}$. In some cases, the cation structural

95 site would be substituted by the nuclides of interest such as contaminated $\operatorname{Li}(\mathrm{I})$ and 96 radioactive $\mathrm{Cs}(\mathrm{I})$.

97 Finally, hydroxyl sodalite membranes can be used for treatment of waste water 98 (Scott et al., 2002; Zeng et al., 2002; Harja et al., 2013), for production of ultra pure 99 water (Khajabi et al., 2010), and for separation of $\mathrm{H}_{2}$ and $\mathrm{CH}_{4}$ (Nabavi et al., 2014). It is 100 also widely used in separation and refinery industries as catalysts, adsorbents, and ion 101 exchangers (Borhade and Wakchaure, 2015). 
103 from electrorefining of spent nuclear fuel, and of sodalite-based waste forms. The

104 solutions associated with salt formations are of high ionic strength, and similar solutions

105 are also employed in the Bayer process for extraction of alumina and the process for

106 synthesizing hydroxyl sodalite at elevated temperatures. Therefore, accurate knowledge

107 of solubilities of sodalite in a wide range of ionic strength solutions at elevated

108 temperatures has important bearings on many fields including nuclear waste

109 management.

110 The objective of this work is to derive solubility constants for the pure hydroxyl

111 end member of sodalite, hydroxyl sodalite (ideal formula, $\mathrm{Na}_{8}\left[\mathrm{Al}_{6} \mathrm{Si}_{6} \mathrm{O}_{24}\right][\mathrm{OH}]_{2} \bullet 3 \mathrm{H}_{2} \mathrm{O}$ ),

112 from the solubility data in a wide range of ionic strength solutions at elevated

113 temperatures, by using the high temperature Al-Si Pitzer model (Xiong, 2013, 2014). 


\section{Evaluating Solubility Constants of Hydroxyl Sodalite at Elevated Temperatures}

In this study, the standard state for a solid phase is defined as its pure end-member

119 with unit activity at temperatures and pressures of interest. The standard state of the

120 solvent in aqueous solutions is pure solvent at temperatures and pressures of interest.

121 The standard state for an aqueous solute is a hypothetical 1 molal (m) solution of infinite

122 dilution at temperatures and pressures of interest.

123 The computer code EQ3/6 Version 8.0a (Wolery et al., 2010; Xiong, 2011) is

124 employed as the modeling platform. The goal of the modeling is to minimize the

125 difference between experimental and model predicted values. A similar modeling 126 approach can be found in Xiong $(2013,2014)$.

127 In the modeling, experimental data are used to generate EQ3/6 input files in the

128 first step. In the second step, the values of the targeted parameter (e.g., log K) are

129 changed until the difference between experimental values (e.g., $m_{\Sigma A l}$ and $m_{\Sigma S i}$ ) and

130 model-produced values predicted by the computer code is minimized. In the third step,

131 the final selected value for the targeted parameter is verified to see how it reproduces

132 experimental data.

133 The uncertainties reported in this study are two standard deviations $(2 \sigma)$. Error

134 propagations are calculated based on uncertainties associated with regressions and 135 equilibrium constants in the model.

136 In Table 1 are listed the Al-Si equilibrium constants for temperature of 25 to $137250^{\circ} \mathrm{C}$. Data were adopted from Xiong $(2013,2014)$.. Similarly, the Pitzer parameters 138 for the respective species for the high temperature Al-Si Pitzer model are tabulated in 139 Table 2 , which is valid to $100^{\circ} \mathrm{C}$. 
141 high ionic strength solutions at temperatures ranging from $30^{\circ} \mathrm{C}$ to $75^{\circ} \mathrm{C}$. The

142 stoichiometry for hydroxyl sodalite is $\mathrm{Na}_{7.26}\left[\mathrm{Al}_{6} \mathrm{Si}_{6.12} \mathrm{O}_{24}\right][\mathrm{OH}]_{1.68} \cdot 2.91 \mathrm{H}_{2} \mathrm{O}$. This

143 stoichiometry slightly deviates from the ideal one. The solubility reaction for the above

144 stoichiometry can be written as follows,

$$
+1.26 \mathrm{OH}^{-}+6.12 \mathrm{H}_{4} \mathrm{SiO}_{4}(\mathrm{aq})
$$

149 Using EQ3/6 Version 8.0a as the modeling platform, the equilibrium constants for 150 Reaction (3) were derived from the solubility data of Zeng and Li (2012) (see Table 3).

\section{3. Model Verification and Validation}

153 In Figures 1 and 2, solubilities of hydroxyl sodalite as a function of ionic strength 154 at $30^{\circ} \mathrm{C}, 45^{\circ} \mathrm{C}, 60^{\circ} \mathrm{C}$ and $75^{\circ} \mathrm{C}$ predicted by the model are compared with the experimental 155 values. As observed the model-predicted values compared favorably well with 156 experimental data, demonstrating the robustness of the model.

157 In Figure 3, the equilibrium constants for hydroxyl sodalite in the temperature 158 range from $30^{\circ} \mathrm{C}$ to $75^{\circ} \mathrm{C}$ are plotted as a function of reciprocal temperatures. It is clear

159 that the relation between $\log \mathrm{K}$ and reciprocal temperatures is highly linear. According to 160 this linear relation, the equilibrium constants at $25^{\circ} \mathrm{C}, 90^{\circ} \mathrm{C}$, and $100^{\circ} \mathrm{C}$, are extrapolated 161 (Table 3). 
Palmer et al. (2001) conducted solubility experiments on hydroxyl sodalite in 0.5

$163 \mathrm{~mol} \cdot \mathrm{kg}^{-1} \mathrm{NaOH}$ with $3.0 \mathrm{~mol} \bullet \mathrm{kg}^{-1} \mathrm{NaNO}_{3}$ at $30^{\circ} \mathrm{C}$. In Figure 1, their model-

164 independent, experimental data are compared with the model-predicted values. Figure 1

165 shows that the model-predicted values are in excellent agreement with their experimental

166 values. Palmer et al. (2001) also presented experimental data in $3.0 \mathrm{~mol} \bullet \mathrm{kg}^{-1} \mathrm{NaOH}$ with

$1673.0 \mathrm{~mol} \cdot \mathrm{kg}^{-1} \mathrm{NaNO}_{3}$ at $63^{\circ} \mathrm{C}$. Their model-independent, experimental data at $63^{\circ} \mathrm{C}$ are

168 compared with the model-predicted values at $60^{\circ} \mathrm{C}$ (Figure 2). Figure 2 indicates that the

169 model-predicted values at $60^{\circ} \mathrm{C}$ are also in excellent agreement with their experimental

170 data at $63^{\circ} \mathrm{C}$.

171 Wajima et al. (2007) obtained solution chemistry for hydroxyl sodalite in high

172 ionic strength $\mathrm{NaOH}$ solutions up to $4.5 \mathrm{~mol} \cdot \mathrm{kg}^{-1}$ at $90^{\circ} \mathrm{C}$. Therefore, their experimental

173 data are used for the validation test for the predicted $\log \mathrm{K}$ at $90^{\circ} \mathrm{C}$ and for the model. In

174 the work of Wajima et al. (2007), concentrations were given on the molarity scale. In the

175 validation test, all of their concentrations on the molar scale were converted to molal

176 scale according to the following equation, based on densities of supporting solutions used

177 in experiments at respective temperatures, which are calculated from density equations of

178 Sőhnel and Novotný (1985),

179

180

$$
m_{i}=\frac{1000 \times M_{i}}{1000 \rho-\sum_{i}^{j} M_{i} E_{i}}
$$

182 where $m_{i}$ is concentration of $i$ species on molality scale, $\rho$ density of solution, $M_{i}$ is 183 concentration of $i$ species on molarity scale, and $E_{i}$ the molecular weight of $i$ species. 
Figure 4 demonstrates that the solubility data produced by the model are in good agreement with the model-independent values from Wajima et al. (2007), especially in the high ionic strength range. Notice that the hydroxyl sodalite in Wajima et al. (2007) was synthesized from the paper-sludge ash, and hence there were other impurities such as $\mathrm{K} . \mathrm{Mg}, \mathrm{Ca}, \mathrm{Fe}$ and $\mathrm{Ti}$, although they were not quantified in solution chemistry in the original work. Therefore, considering the effect of other impurities as they may have different specific interaction effects with $\mathrm{Al}$ and $\mathrm{Si}$, the agreement between the modelpredicted values and the experimental values is satisfactory in the relatively low ionic strength range.

\section{Applications}

In this section, the solubility constants obtained in this work are applied to generic repositories in salt formations and granite to evaluate the performance of hydroxyl sodalite up to $100^{\circ} \mathrm{C}$. For a generic repository in salt formations, it is assumed that the brine is dominated by sodium and chloride, and is saturated with halite. For instance, the Waste Isolation Pilot Plant (WIPP) brines, GWB and ERDA-6, are dominated by sodium and chloride (Xiong and Lord, 2008). The $\mathrm{Na}^{+}$and $\mathrm{Cl}^{-}$concentrations are $4.04 \mathrm{~mol} \cdot \mathrm{kg}^{-1}$ and $6.40 \mathrm{~mol} \bullet \mathrm{kg}^{-1}$ for GWB, and $5.35 \mathrm{~mol} \bullet \mathrm{kg}^{-1}$ and $5.27 \mathrm{~mol} \cdot \mathrm{kg}^{-1}$ for ERDA-6, respectively (Xiong and Lord, 2008). It is also assumed that the hydrogen ion concentration of the brine on a molal scale (i.e., $\mathrm{pH}_{\mathrm{m}}$ ) is controlled by equilibrium with brucite, as brucite has been proposed as the engineered barrier for the geological repository in a domal salt formation at Asse, Germany (Schuessler et al., 2002), and MgO has been emplaced in the WIPP as the engineered barrier (Xiong and Lord, 2008).

$$
\mathrm{NaCl}(\mathrm{cr}) \rightleftarrows \mathrm{Na}^{+}+\mathrm{Cl}^{-}
$$


214 were taken from the EQ3/6 database (Wolery, 1992). The equilibrium constants for 215 dissolution of brucite,

$$
\mathrm{Mg}(\mathrm{OH})_{2}(\mathrm{cr})+2 \mathrm{H}^{+} \rightleftarrows \mathrm{Mg}^{2+}+2 \mathrm{H}_{2} \mathrm{O}(\mathrm{l})
$$

the value at $25^{\circ} \mathrm{C}$ is from Xiong (2008). The values above $25^{\circ} \mathrm{C}$ are from Brown et al. 220 (1996).

$221 \quad$ For the first hydrolysis reaction of $\mathrm{Mg}^{2+}$,

$$
\mathrm{Mg}^{2+}+\mathrm{H}_{2} \mathrm{O}(\mathrm{l})=\mathrm{MgOH}^{+}+\mathrm{H}^{+}
$$

the equilibrium constants above $25^{\circ} \mathrm{C}$ were from $\mathrm{McGee}$ and Hostetler (1975).

In Figure 5, displayed are the predicted solubility products of hydroxyl sodalite in 227 terms of $m_{\Sigma A l} \times m_{\Sigma S i}$ as a function of reciprocal temperatures for a generic repository in 228 salt formations. As indicated by Figure 5, the performance of hydroxyl sodalite in such a generic repository is expected to be excellent because of its low solubilities. Its solubility 230 products at $25^{\circ} \mathrm{C}$ and $100^{\circ} \mathrm{C}$ are in the range of $\sim 2 \times 10^{-11}$ and $\sim 10^{-13}\left(\mathrm{~mol}^{\circ} \mathrm{kg}^{-1}\right)^{2}$, 231 respectively, i.e., its solubility on the order of $\sim 10^{-5.5}$ and $\sim 10^{-6.5} \mathrm{~mol} \bullet \mathrm{kg}^{-1}$, indicating 232 that it is very stable in salt formations (Figure 5).

233 In Figure 5, the predicted solubility products of hydroxyl sodalite for a generic 234 repository in granite are also shown. The chemical compositions for the solution in such 235 a generic repository are assumed to be similar to those at Olkiuoto, Finland (Table 4) 236 (Pitkänen et al., 2007; POSIVA, 2010), a geological repository in granite. For simplicity, $237 \mathrm{pH}_{\mathrm{m}}$ is also assumed to be controlled by dissolution of brucite in the calculations. This 238 assumption is reasonable, as the reaction of the groundwater with the corrosion 239 product(s) of low carbon steel canisters such as $\mathrm{Fe}(\mathrm{OH})_{2}$ would make the near-field 240 environments mildly alkaline, favoring formation of brucite. Notice that the groundwater 241 already contains magnesium concentrations in milli-molal range (Table 4). The predicted 242 solubility products of hydroxyl sodalite in terms of $m_{\Sigma A l} \times m_{\Sigma S i}$ in a generic repository in 243 granite are higher than those in salt formations (Figure 5). The solubility products at 
$24425^{\circ} \mathrm{C}$ and $100^{\circ} \mathrm{C}$ are in the orders of $\sim 5 \times 10^{-8}$ and $\sim 2 \times 10^{-10}\left(\mathrm{~mol} \cdot \mathrm{kg}^{-1}\right)^{2}$, respectively,

245 indicating that its solubility is in the order of $\sim 2 \times 10^{-4}$ and $\sim 10^{-5} \mathrm{~mol} \cdot \mathrm{kg}^{-1}$ at $25^{\circ} \mathrm{C}$ and

$246100^{\circ} \mathrm{C}$, respectively (Figure 5). This would suggest that the performance of hydroxyl

247 sodalite in a generic repository in granite is still good.

248 The above assessment concerns only the pure end member of hydroxyl sodalite.

249 As the solubilities of other sodalites such as iodide-sodalite are expected to behave

250 similarly to that of hydroxyl sodalite, it can be anticipated that the disposal of them in a

251 generic repository in salt formations would also exhibit excellent performance. However,

252 further studies on other sodalites are an important subject. When the systematic data for

253 other sodalites become available, further model development will be followed.

\section{Conclusions}

In this study, equilibrium constants for hydroxyl sodalite were obtained up to

$259100^{\circ} \mathrm{C}$ by applying the high temperature Al-Si Pitzer model to evaluate the solubility data

260 for high ionic strength solutions, up to $\sim 11 \mathrm{~mol} \bullet \mathrm{kg}^{-1}$. The solubility constants at $30^{\circ} \mathrm{C}$,

$26160^{\circ} \mathrm{C}$, and $90^{\circ} \mathrm{C}$ are validated by the model-independent, experimental data. It is expected

262 that the model equilibrium constants can be applicable in such fields such as synthesis of

263 hydroxyl sodalite for treatment of waste water, the evaluation of the performance of the

264 sodalite waste forms for various nuclear wastes, and de-silication in the Bayer process for

265 extraction of alumina.

266 Although there are no direct studies for comparing the durability of natural

267 sodalite with that of synthetic sodalite, it would be expected that the durability of

268 synthetic sodalite would be similar to that of natural sodalite. This is because the

269 solubility of synthetic sodalite in terms of $\mathrm{Al}$ and $\mathrm{Si}$ is close to, or below, the background

270 of the groundwater. For instance, the solution product of $m_{\Sigma A l} \times m_{\Sigma S i}$ at $80^{\circ} \mathrm{C}$ in granite 
271 rock is on the order of $10^{-7}\left(\mathrm{~mol} \cdot \mathrm{kg}^{-1}\right)^{2}$ (Savage et al., 1992). In comparison, the

272 solubility product of $m_{\Sigma A l} \times m_{\Sigma S i}$ for hydroxyl sodalite at $80^{\circ} \mathrm{C}$ in a generic granite

273 repository is on the order of $10^{-9}\left(\mathrm{~mol} \cdot \mathrm{kg}^{-1}\right)^{2}$, as indicated by Figure 5 .

274

275

276

277

278

279

280 the U.S. Department of Energy's National Nuclear Security Administration under

281 contract DE-AC04-94AL85000. This research was supported by the Salt R\&D Programs

282 administrated by the Office of Nuclear Energy, U.S. Department of Energy. SAND2016-

283 2300J. The author is grateful to the three journal reviewers, and thanks for their detailed

284 and insightful reviews, which have improved the paper. The author would like to thank

285 Dr. Michael Kersten, the journal editor, for his editorial efforts. 


\section{References}

Azaroual, M., Fouillac, C., and Matray, J.M., 1997. Solubility of silica polymorphs in electrolyte solutions, I. Activity coefficient of aqueous silica from $25{ }^{\circ} \mathrm{C}$ to $250{ }^{\circ} \mathrm{C}$, Pitzer's parameterization. Chemical Geology, 140, 155-165.

Borhade, A.V., Dholi, A.G., Wakchaure, S.G., and Tope, D.R., 2012. Chemical modification of coal fly ash into iodate sodalite and its use for the removal of $\mathrm{Cd}^{2+}, \mathrm{Pb}^{2+}$, and $\mathrm{Zn}^{2+}$ from their aqueous solutions. Desalination and Water Treatment 50, 157-169.

Borhade, A.V., and Wakchaure, S.G., 2015. Synthesis and characterization of silver and cesium derivatives of $\left.\mathrm{Na}_{8}\left[\mathrm{GaSiO}_{4}\right]_{6} \mathrm{OH}\right)_{2}$ sodalite. Russian Journal of Physical Chemistry A 89, 384-388.

Bronić, J., Subotić, B., \& Brlek, Đ. (2008, January). INFLUENCE OF ALCALINITY ON SYNTHESIS OF ZEOLITE A. In Prvi hrvatsi zeolitni simpozij-First Croatian Symposium on Zeolites. Hrvatska znanstvena bibliografija i MZOS-Svibor.

Brown, P.L., Drummond, S.E. and Palmer, D.A., 1996. Hydrolysis of magnesium (II) at elevated temperatures. Journal of the Chemical Society, Dalton Transactions, (14), pp.3071-3075.

Capone, M., de Angelis, G., Fedeli, C., Giacobbo, F., da Ros, M., Macerata, E., Mariani, M., 2014. Leaching behavior of salt wastes conditioned with sodalite blended with two different glass powders. Advances in Science and Technology 94, 131-136.

Dickson, J.O., Harsh, J. B., Flury, M., Pierce, E.M., 2015a. Immobilization and exchange of perrhenate in sodalite and cancrinite. Microporous and Mesoporous Materials 214, 115-120.

Dickson, J.O., Harsh, J. B., Lukens, W.W., Pierce, E.M., 2015b. Perrhenate incorporation into binary mixed sodalites: The role of anion size and implications for technetium-99 sequestration. Chemical Geology 395, 138-143.

Gilbert, M. R., 2013. Towards a silicate matrix for the immobilisation of halide-rich wastes. MRS Proceedings 1518, 91-96.

Gilbert, M. R., 2015. Pressureless sintering of sodalite waste-forms for the immobilization of pyroprocessing wastes. MRS Proceedings 1744, 61-66.

Harja, M., Buema, G., Sutiman, D., and Cretescu, I., 2013. Removal of heavy metal ions from aqueous solutions using low-cost sorbents obtained from ash. Chemical Papers 67, 497-508.

Helgeson, H.C., and Kirkham, D.H. (1974) Theoretical prediction of the thermodynamic behavior of aqueous electrolytes at high pressures and temperatures. II. Debye-Hückel 
parameters for activity coefficients and relative partial molal properties. American Journal of Sciences, 274, 1199-1261.

Hershey, J.P., and Millero, F.J., 1986. The dependence of the acidity constants of silicic acid on $\mathrm{NaCl}$ concentration using Pitzer's equation. Marine Chemistry 18, 101-105.

Hirabayashi, D., Tanada, Y., Sugiyama, T., Enokida, Y., and Sawada, K., 2012. Low-temperature conversion of spent adsorbent to iodine sodalite by a mechanochemical route. AIChE Journal 58, 2441-2447.

Khajavi, S., Jansen, J.C., and Kapteijn, F., 2010. Production of ultra pure water by desalination of seawater using a hydroxy sodalite membrane. Journal of Membrane Science 356, 52-7.

Lepry, W. C., Riley, B. J., Crum, J. V., Rodriguez, C. P., and Pierce, D. A., 2013. Solution-based approaches for making high-density sodalite waste forms to immobilize spent electrochemical salts. Journal of Nuclear Materials 442, 350-359.

Luksic, S.A., Riley, B.J., Schweiger, M., Hrma, P., 2015. Incorporating technetium in minerals and other solids: A review. Journal of Nuclear Materials 466, 526-538.

Maddrell, E., Gandy, A., and Stennett, M., 2014. The durability of iodide sodalite. Journal of Nuclear Materials 449, 168-72.

Mattigod, S.V., McGrail, B.P., McCready, D.E., Wang, L.-Q., Parker K.E., and Young, A.S., 2006. Synthesis and structure of perrhenate sodalite. Microporous and Mesoporous Materials 91, 139-144.

McGee, K.A., Hostetler, P.B., 1975. Studies in the system $\mathrm{MgO}-\mathrm{SiO}_{2}-\mathrm{CO}_{2}-\mathrm{H}_{2} \mathrm{O}$ (IV); The stability of $\mathrm{MgOH}^{+}$from $10^{\circ} \mathrm{C}$ to $90^{\circ} \mathrm{C}$. American Journal of Science $275,304-317$.

Missimer, D., Rutherford, R., 2013. Preparation and initial characterization of fluidized bed steam reforming pure-phase standards. SRNL-STI-2013-00111, Savannah River National Laboratory, Aiken, SC.

Morss, L.R., Lewis, M.A., Richmann, M.K., Lexa, D., 2000. Cerium, uranium, and plutonium behavior in glass-bonded sodalite, a ceramic nuclear waste form. Journal of Alloys and Compounds 303-304, 42-48.

Nabavi, M.S., Mohammadi, T., Kazemimoghadam, M., 2014. Hydrothermal synthesis of hydroxy sodalite zeolite membrane: Separation of $\mathrm{H}_{2} / \mathrm{CH}_{4}$. Ceramics International 40, 5889-5896.

Novak, C.F., 1996. Development of the FMT chemical transport simulator: coupling aqueous density and mineral volume fraction to phase compositions. Journal of Contaminant Hydrology 21, 297-310. 
Palmer, D.A., Benezeth, P., Wesolowski, D., Hilic, S., 2001. Experimental study of the dissolution of aluminum phases as a function of temperature, caustic concentration and additives. Oak Ridge National Laboratories, RPT 120198.

Park, W., Hur, J.M., Hong, S.S., Choi, E.Y., Im, H.S., Oh, S.C. and Lee, J.W., 2013. An experimental study for $\mathrm{Li}$ recycling in an electrolytic reduction process for $\mathrm{UO}_{2}$ with a $\mathrm{Li}_{2} \mathrm{O}-\mathrm{LiCl}$ molten salt. Journal of Nuclear Materials 441, 232-239.

Pierce, E.M., Lukens, W.W., Fitts, J.P., Jantzen, C.M., Tang, G., 2014. Experimental determination of the speciation, partitioning, and release of perrhenate as a chemical surrogate for pertechnetate from a sodalite-bearing multiphase ceramic waste form. Applied Geochemistry 42, 47-59.

Pitkänen, P., Ahokas, H., Ylä-Mella, M., Partamies, S., Snellman, M. and Hellä, P. 2007. Quality review of hydrochemical baseline data from the Olkiluoto site. Olkiluoto, Finland: Posiva Oy. Report POSIVA 2007-05.

Pitzer, K.S., 1991. Ion interaction approach: theory and data correlation. In Pitzer, K.S., editor, Activity Coefficients in Electrolyte Solutions, 2nd edition, CRC Press, Boca Raton, Florida, p. 75-153.

POSIVA, 2010. Models and Data Report 2010. POSIVA 2010-01. Posiva Oy, Olkiluoto, Finland.

Priebe, S, Bateman, K. 2006. The Ceramic Waste Form Process at the Idaho National Laboratory (No. INL/CON-06-11606). Idaho National Laboratory (INL).

Priebe, S, Bateman, K., 2008. The ceramic waste form process at Idaho National Laboratory. Nuclear Technology 162, 199-207.

Savage, D., Bateman, K. and Richards, H.G., 1992. Granite-water interactions in a flowthrough experimental system with applications to the Hot Dry Rock geothermal system at Rosemanowes, Cornwall, UK. Applied geochemistry, 7(3), pp.223-241.

Schuessler, W., Metz, V., Kienzler, B., Vejmelka, P., 2002. Geochemically based source term assessment for the Asse salt mine: Comparison of modeling and experimental results (abstract). Programs and Abstracts of Materials Research Society Annual Meeting at Boston, MA, p. 713.

Scott, J., Guang, D., Naeramitmarnsuk, K., Thabuot, M., Amal, R., 2002. Zeolite synthesis from coal fly ash for the removal of lead ions from aqueous solution. Journal of Chemical Technology and Biotechnology 77, 63-69. 
Sheppard, G.P., Hriljac, J.A., Maddrell, E.R., Hyatt, N., 2006. Silver zeolites: Iodide occlusion and conversion to sodalite-a potential ${ }^{129}$ I waste form? Materials Research Society Symposium Proceeding, Vol. 932, 8 pp.

Sőhnel, O. and Novotný, P., 1985. Densities of aqueous solutions of inorganic substances. Elsevier, New York, 335 p.

Vance, E.R. and Adl, T., 1981. Leaching studies of crystalline sodium phases in nuclear waste forms. MRS Proceedings 6, 163.

Wajima, T., Ishimoto, H., Kuzawa, K., Ito, K., Tamada, O., Gunter, M.E., Rakovan, J.F., 2007. Material conversion from paper-sludge ash in $\mathrm{NaOH}, \mathrm{KOH}$, and $\mathrm{LiOH}$ solutions. American Mineralogist 92, 1105-1111.

Wesolowski, D.J., 1992. Aluminum speciation and equilibrium in aqueous solution: I. The solubility of gibbsite in the system Na-K-Cl-OH-Al(OH$)_{4}$ from $0{ }^{\circ} \mathrm{C}$ to $100{ }^{\circ} \mathrm{C}$. Geochimica et Cosmochimica Acta 56, 1065-1091.

Wolery, T.J., 1992. EQ3/6, A Software Package for Geochemical Modeling of Aqueous Systems: UCRL-MA-110662 PT I. Lawrence Livermore National Laboratory, Livermore, CA, USA.

Wolery, T.W., Xiong, Y.-L., Long, J. (2010) Verification and Validation Plan/Validation Document for EQ3/6 Version 8.0a for Actinide Chemistry, Document Version 8.10. Carlsbad, NM: Sandia National laboratories. ERMS 550239.

Xiong, Y.-L., 2008. Thermodynamic properties of brucite determined by solubility studies and their significance to nuclear waste isolation. Aquatic Geochemistry 14, 223238.

Xiong, Y.-L., 2011 WIPP Verification and Validation Plan/Validation Document for EQ3/6 Version 8.0a for Actinide Chemistry, Revision 1, Document Version 8.20. Supersedes ERMS 550239. Carlsbad, NM. Sandia National Laboratories. ERMS 555358.

Xiong, Y.-L., 2013. A thermodynamic model for silica and aluminum in alkaline solutions with high ionic strength at elevated temperatures up to $100{ }^{\circ} \mathrm{C}$ : Applications to zeolites. American Mineralogist 98, 141-153.

Xiong, Y.-L., 2014. A Pitzer Model for the $\mathrm{Na}-\mathrm{Al}(\mathrm{OH})_{4}-\mathrm{Cl}-\mathrm{OH}$ System and Solubility of Boehmite (AlOOH) to High Ionic Strength and to $250^{\circ} \mathrm{C}$. Chemical Geology 373, 37-49.

Xiong, Y. - L., and Lord, A.S., 2008. Experimental investigations of the reaction path in the $\mathrm{MgO}-\mathrm{CO}_{2}-\mathrm{H}_{2} \mathrm{O}$ system in solutions with various ionic strengths, and their applications to nuclear waste isolation. Applied Geochemistry 23, 1634-1659. 
470 Zeng, L.M., Li, Z.-B., 2012. Solubility and modeling of sodium aluminosilicate in $471 \mathrm{NaOH}-\mathrm{NaAl}(\mathrm{OH})_{4}$ solutions and its application to desilication. Industrial \& Engineering 472 Chemistry Research 51, 15192-15206.

473

474 Zeng, R., Umana, J.C., Querol, X., Lopez-Soler, A., Plana, F., Zhuang, X., 2002. Zeolite 475 synthesis from a high Si-Al fly ash from East China. Journal of Chemical Technology

476 and Biotechnology 77, 267-273.

477

478 
Table 1. Equilibrium constants for silica and aluminum species considered in the Al-Si Pitzer model of Xiong $\left(2013,2014\right.$, references therein) up to $250{ }^{\circ} \mathrm{C}$

\begin{tabular}{|c|c|c|}
\hline Reaction & $\mathrm{T},{ }^{\circ} \mathrm{C}$ & $\log \mathrm{K}$ \\
\hline \multirow[t]{4}{*}{$\mathrm{H}_{4} \mathrm{SiO}_{4}=\mathrm{H}^{+}+\mathrm{H}_{3} \mathrm{SiO}_{4}^{-}$} & 25 & $-9.68 \pm 0.14$ \\
\hline & 50 & $-9.34 \pm 0.16$ \\
\hline & 75 & $-9.10 \pm 0.17$ \\
\hline & 100 & $-8.94 \pm 0.16$ \\
\hline \multirow[t]{4}{*}{$\mathrm{H}_{3} \mathrm{SiO}_{4}^{-}=\mathrm{H}^{+}+\mathrm{H}_{2} \mathrm{SiO}_{4}^{2-}$} & 25 & $-13.45 \pm 0.07$ \\
\hline & 50 & $-12.95 \pm 0.25$ \\
\hline & 75 & $-12.56 \pm 0.25$ \\
\hline & 100 & $-12.28 \pm 0.25$ \\
\hline \multirow[t]{4}{*}{$2 \mathrm{H}_{4} \mathrm{SiO}_{4}=\mathrm{H}^{+}+\mathrm{H}_{5} \mathrm{Si}_{2} \mathrm{O}_{7}^{-}+\mathrm{H}_{2} \mathrm{O}$} & 25 & -8.50 \\
\hline & 50 & $-8.14 \pm 0.25$ \\
\hline & 75 & $-7.86 \pm 0.25$ \\
\hline & 100 & $-7.65 \pm 0.25$ \\
\hline \multirow[t]{4}{*}{$\mathrm{H}_{5} \mathrm{Si}_{2} \mathrm{O}_{7}^{-}=\mathrm{H}^{+}+\mathrm{H}_{4} \mathrm{Si}_{2} \mathrm{O}_{7}^{2-}$} & 25 & -10.90 \\
\hline & 50 & $-10.59 \pm 0.25$ \\
\hline & 75 & $-10.38 \pm 0.25$ \\
\hline & 100 & $-10.24 \pm 0.25$ \\
\hline \multirow[t]{4}{*}{$3 \mathrm{H}_{4} \mathrm{SiO}_{4}=3 \mathrm{H}^{+}+\mathrm{H}_{5} \mathrm{Si}_{3} \mathrm{O}_{10}{ }^{3-}+2 \mathrm{H}_{2} \mathrm{O}$} & 25 & -29.40 \\
\hline & 50 & $-28.75 \pm 0.25$ \\
\hline & 75 & $-28.34 \pm 0.25$ \\
\hline & 100 & $-28.11 \pm 0.25$ \\
\hline \multirow[t]{4}{*}{$\mathrm{Al}(\mathrm{OH})_{4}^{-}=\mathrm{Al}^{3+}+4 \mathrm{OH}^{-}$} & 25 & $-34.05 \pm 0.05$ \\
\hline & 50 & $-33.44 \pm 0.05$ \\
\hline & 75 & $-33.11 \pm 0.05$ \\
\hline & 100 & $-32.99 \pm 0.05$ \\
\hline \multirow[t]{4}{*}{$\mathrm{AlOOH}(\mathrm{cr})+2 \mathrm{H}_{2} \mathrm{O}=\mathrm{H}^{+}+\mathrm{Al}(\mathrm{OH})_{4}^{-}$} & 100 & $-12.89 \pm 0.04$ \\
\hline & 150 & $-12.03 \pm 0.05$ \\
\hline & 200 & $-11.34 \pm 0.05$ \\
\hline & 250 & $-10.98 \pm 0.06$ \\
\hline \multirow[t]{5}{*}{$\mathrm{Al}(\mathrm{OH})_{4}{ }^{-}+\mathrm{H}_{2} \mathrm{SiO}_{4}{ }^{2-}=\mathrm{Al}(\mathrm{OH})_{3} \mathrm{HSiO}_{4}{ }^{3-}+\mathrm{H}_{2} \mathrm{O}(\mathrm{l})$} & 20 & $-0.42 \pm 0.10$ \\
\hline & 25 & $-0.42 \pm 0.15$ \\
\hline & 50 & $-0.38 \pm 0.25$ \\
\hline & 75 & $-0.35 \pm 0.25$ \\
\hline & 100 & $-0.33 \pm 0.25$ \\
\hline
\end{tabular}

482

483 
Table 2. Pitzer interaction parameters employed in this study

\begin{tabular}{|c|c|c|c|c|c|}
\hline \multicolumn{6}{|c|}{ Binary Interaction Parameters } \\
\hline Interaction Pair & \multicolumn{2}{|c|}{$\beta^{(0)}$} & $\beta^{(1)}$ & $\mathrm{C}^{\phi}$ & References \\
\hline $\mathrm{Na}^{+}-\mathrm{H}_{3} \mathrm{SiO}_{4}^{-}$ & \multicolumn{2}{|c|}{$0.043 \pm 0.019$} & $0.24 \pm 0.11$ & & Hershey and Millero (1986) \\
\hline $\mathrm{Na}^{+}-\mathrm{H}_{2} \mathrm{SiO}_{4}{ }^{2-}$ & \multicolumn{2}{|c|}{$0.32 \pm 0.08$} & $0.13 \pm 0.50$ & & Hershey and Millero (1986) \\
\hline $\mathrm{Na}^{+}-\mathrm{H}_{5} \mathrm{Si}_{2} \mathrm{O}_{7}^{-}$ & \multicolumn{2}{|c|}{$-0.0571 \pm 0.04$} & $0.34 \pm 0.13$ & & Xiong $(2013)$ \\
\hline $\mathrm{Na}^{+}-\mathrm{H}_{4} \mathrm{Si}_{2} \mathrm{O}_{7}^{2-}$ & \multicolumn{2}{|c|}{$-0.0227 \pm 0.06$} & $1.56 \pm 0.40$ & & Xiong (2013) \\
\hline $\mathrm{Na}^{+}-\mathrm{H}_{5} \mathrm{Si}_{3} \mathrm{O}_{10}^{3-}$ & \multicolumn{2}{|c|}{$0.078 \pm 0.03$} & $4.29 \pm 0.80$ & & Xiong (2013) \\
\hline $\mathrm{Na}^{+}-\mathrm{Al}(\mathrm{OH})_{3} \mathrm{HSiO}_{4}{ }^{3-}$ & \multicolumn{2}{|c|}{$0.078 \pm 0.03$} & $4.29 \pm 0.80$ & & Xiong (2013) \\
\hline $\mathrm{Na}^{+}-\mathrm{Al}(\mathrm{OH})_{4}^{-}$ & \multicolumn{2}{|c|}{0.051} & 0.25 & -0.00090 & Wesolowski (1992) \\
\hline \multicolumn{6}{|c|}{ Interaction Involving Neutral Species and Mixing Parameters } \\
\hline Interaction Pair & $\lambda_{\mathrm{ij}}$ & & $\theta_{\mathrm{ij}}$ & $\Psi_{\mathrm{ijk}}$ & References \\
\hline $\mathrm{Na}^{+}-\mathrm{H}_{4} \mathrm{SiO}_{4}{ }^{0}$ & 0.0925 & & & & Azaroual et al. (1997) \\
\hline $\mathrm{OH}^{-}-\mathrm{H}_{2} \mathrm{SiO}_{4}^{2-}$ & & $\begin{array}{r}-0 . \\
-9.3\end{array}$ & $\begin{array}{l}12 \pm 0.003 \\
\left.\frac{\theta_{i j}}{\partial T}\right)_{P}= \\
0.44 \times 10^{-5}\end{array}$ & & Xiong (2013) \\
\hline $\mathrm{OH}^{-}-\mathrm{H}_{2} \mathrm{SiO}_{4}^{2-}-\mathrm{Na}^{+}$ & & & & $-0.017 \pm 0.02$ & Xiong (2013) \\
\hline $\mathrm{OH}^{-}-\mathrm{Al}(\mathrm{OH})_{4}^{-}-\mathrm{Na}^{+}$ & & & & -0.04800 & Wesolowski (1992) \\
\hline $\mathrm{Cl}^{-}-\mathrm{Al}(\mathrm{OH})_{4}^{-}-\mathrm{Na}^{+}$ & & & & -0.04857 & Xiong (2014) \\
\hline
\end{tabular}


Table 3. Equilibrium constants of hydroxyl sodalite retrieved from solubility experiments in this study

\begin{tabular}{|c|c|c|}
\hline Reaction & $\mathrm{T},{ }^{\circ} \mathrm{C}$ & $\log K^{0}$ \\
\hline \multirow{7}{*}{$\begin{array}{l}\mathrm{Na}_{7.26} \mathrm{Al}_{6} \mathrm{Si}_{6.21} \mathrm{O}_{24.03}(\mathrm{OH})_{1.68} \cdot 2.91 \mathrm{H}_{2} \mathrm{O}(\mathrm{cr})+21.12 \mathrm{H}_{2} \mathrm{O}(\mathrm{l})= \\
\quad 7.26 \mathrm{Na}^{+}+6 \mathrm{Al}(\mathrm{OH})_{4}{ }^{-}+1.26 \mathrm{OH}^{-}+6.12 \mathrm{H}_{4} \mathrm{SiO}_{4}(\mathrm{aq})\end{array}$} & 25 & $-60.34^{A}$ \\
\hline & 30 & -61.18 \\
\hline & 45 & -64.20 \\
\hline & 60 & -66.69 \\
\hline & 75 & -68.89 \\
\hline & 90 & $-71.26^{\mathrm{A}}$ \\
\hline & 100 & $-72.68^{A}$ \\
\hline \multicolumn{3}{|c|}{$\begin{array}{l}\text { A Extrapolated values, based on the linear relation between } \log K \text { and reciprocal } \\
\text { temperature in Kevin for hydroxyl sodalite. }\end{array}$} \\
\hline
\end{tabular}


Table 4. The chemical compositions of the groundwater for the geological repository in granite at Olkiluoto, Finland*

\begin{tabular}{|c|c|c|c|c|c|c|}
\hline $\begin{array}{l}\text { Total } \\
\text { Dissoved Salts } \\
\text { (TDS), mg/L }\end{array}$ & $\begin{array}{l}\text { Ionic } \\
\text { Strength, } \\
\text { mol•kg }\end{array}$ & $\mathrm{pH}^{* *}$ & $\begin{array}{l}\mathrm{Na}^{+} \\
\mathrm{mol} \cdot \mathrm{kg}^{-1}\end{array}$ & $\begin{array}{l}\mathrm{K}^{+} \\
\mathrm{mol} \cdot \mathrm{kg}^{-1}\end{array}$ & $\begin{array}{l}\mathrm{Mg}^{2+} \\
\mathrm{mol} \cdot \mathrm{kg}^{-1}\end{array}$ & $\begin{array}{l}\mathrm{Ca}^{2+} \\
\mathrm{mol} \cdot \mathrm{kg}^{-1}\end{array}$ \\
\hline 49,483 & 1.36 & 8.2 & 0.3672 & $5.0 \times 10^{-4}$ & 0.0015 & 0.2590 \\
\hline 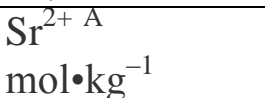 & $\begin{array}{l}\mathrm{Mn}^{2+\mathrm{A}} \\
\mathrm{mol} \cdot \mathrm{kg}^{-1}\end{array}$ & $\begin{array}{l}\mathrm{Cl}^{-} \\
\mathrm{mol} \cdot \mathrm{kg}^{-1}\end{array}$ & $\begin{array}{l}\mathrm{SO}_{4}{ }^{2-} \\
\mathrm{mol} \cdot \mathrm{kg}^{-1}\end{array}$ & $\begin{array}{l}\Sigma \mathrm{H}_{4} \mathrm{SiO}_{4} \\
\mathrm{~mol} \cdot \mathrm{kg}^{-1}\end{array}$ & $\begin{array}{l}\Sigma \mathrm{CO}_{3}{ }^{2-} \\
\mathrm{mol} \cdot \mathrm{kg}^{-1}\end{array}$ & $\begin{array}{l}\sum \mathrm{Al}^{3+\mathrm{B}} \\
\mathrm{mol} \bullet \mathrm{kg}^{-1}\end{array}$ \\
\hline 0.00116 & $9.5 \times 10^{-5}$ & 0.8783 & $5 \times 10^{-5}$ & $2.1 \times 10^{-4}$ & $4 \times 10^{-5}$ & $1 \times 10^{-20}$ \\
\hline
\end{tabular}

* The chemical compositions refer to the groundwater from the OL-KR12 borehole at the

494 depth of $708 \mathrm{~m}$ taken from Pitkanen et al. (2007) and POSIVA (2010). The original

495 concentrations on molar scale $\left(\mathrm{mol} \bullet \mathrm{dm}^{-3}\right)$ are converted to those on molal scale

$496\left(\mathrm{~mol} \bullet \mathrm{kg}^{-1}\right)$ based on the solution density $(1.0323 \mathrm{~g} / \mathrm{mL})$ calculated from TDS, according

497 to the density model of $\mathrm{NaCl}$ solutions in the Fracture Matrix Transport (FMT) code

498 (Novak, 1996).

$499 * *$ In POSIVA (2010), the $\mathrm{pH}$ is 8.2. In the model calculations, the $\mathrm{pH}$ is assumed to be 500 controlled by brucite.

501 A Those components are not inputed for the calculation of hydroxyl sodalite solubility, as

502 they are not supported by the database and do not affect hydroxyl sodalite solubility.

$503{ }^{B}$ Aluminum concentrations are not presented in Pitkanen et al. (2007) and POSIVA

504 (2010). For the purpose of reaction path calculations, an initial concentration of $10^{-20}$

$505 \mathrm{~mol} \cdot \mathrm{kg}^{-1}$ is assigned.

506

507 


\section{Figure Captions}

512 Figure 1. A plot showing the model predicted solubility of hydroxyl sodalite as a 513 function of ionic strengths at $30^{\circ} \mathrm{C}$ and $45^{\circ} \mathrm{C}$ in comparison with experimental values. 514 The size of error bars is equal to or smaller than the symbol size. For the reaction 515 equation, please see Eq. 3 in text.

Figure 2. A plot showing the model predicted solubility of hydroxyl sodalite as a 518 function of ionic strength at $60^{\circ} \mathrm{C}$ and $75^{\circ} \mathrm{C}$ in comparison with experimental values. The 519 size of error bars is equal to or smaller than the symbol size. For the reaction equation, 520 please see Eq. 3 in text.

Figure 3. A plot showing equilibrium constants of hydroxyl sodalite as a function of reciprocal temperatures in Kevin.

Figure 4. A plot showing comparison of model predicted solubilities of hydroxyl sodalite as a function ionic strengths with experimental values, which are independent from the model development. The size of error bars is equal to or smaller than the symbol size.

Figure 5. A plot showing predicted solubilities of hydroxyl sodalite as a function of reciprocal temperatures for a generic repository in salt formations assuming that brine is dominated by $\mathrm{Na}^{+}$and $\mathrm{Cl}^{-}$and hydrogen ion concentrations $\left(\mathrm{pH}_{\mathrm{m}}\right)$ are controlled by dissolution of brucite, and for a generic repository in granite assuming that the groundwater compositions are similar to those at Olkiluoto, Finland (see text for details), and $\mathrm{pH}_{\mathrm{m}}$ are also controlled by dissolution of brucite. 


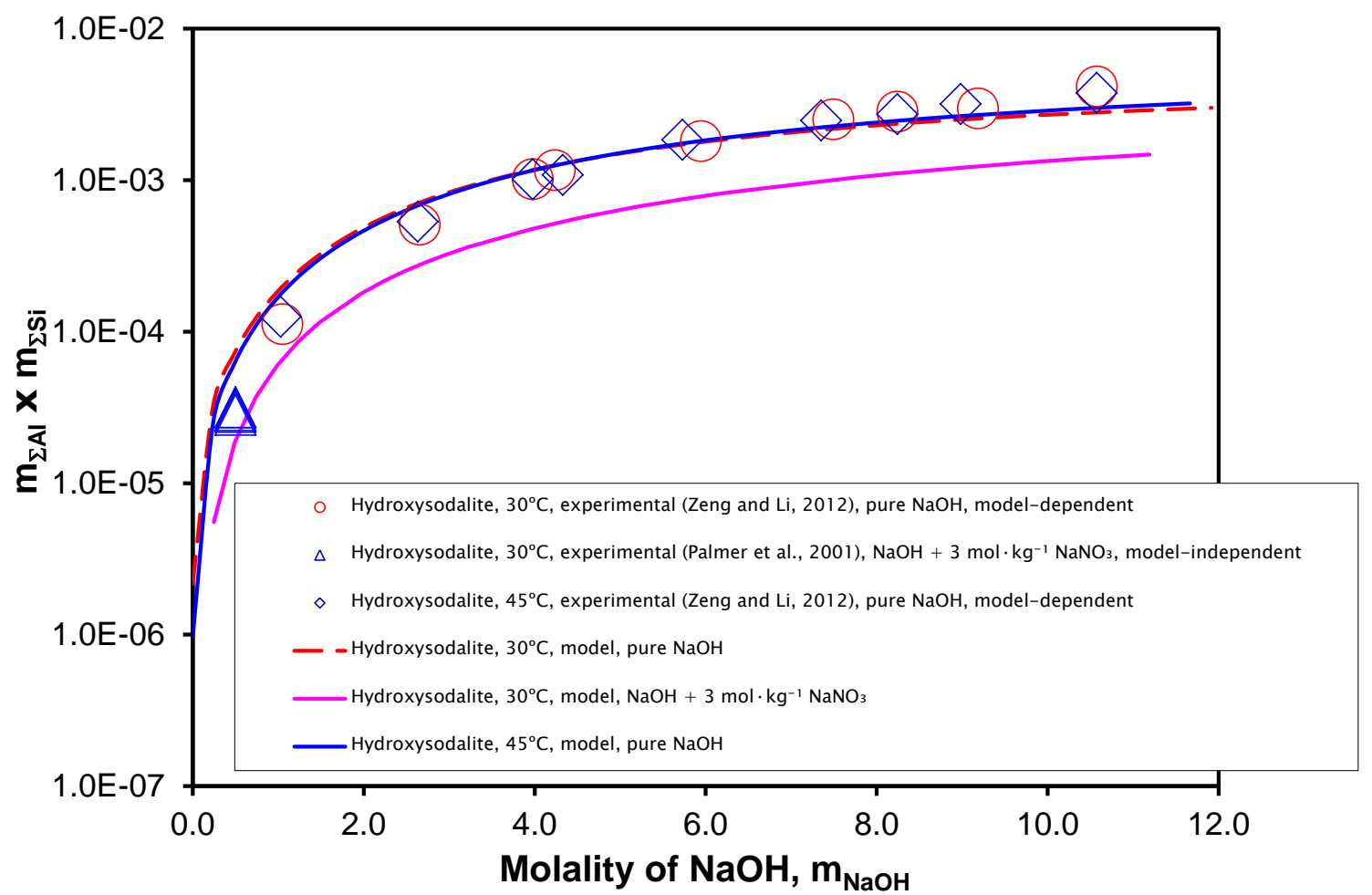

Figure 1 


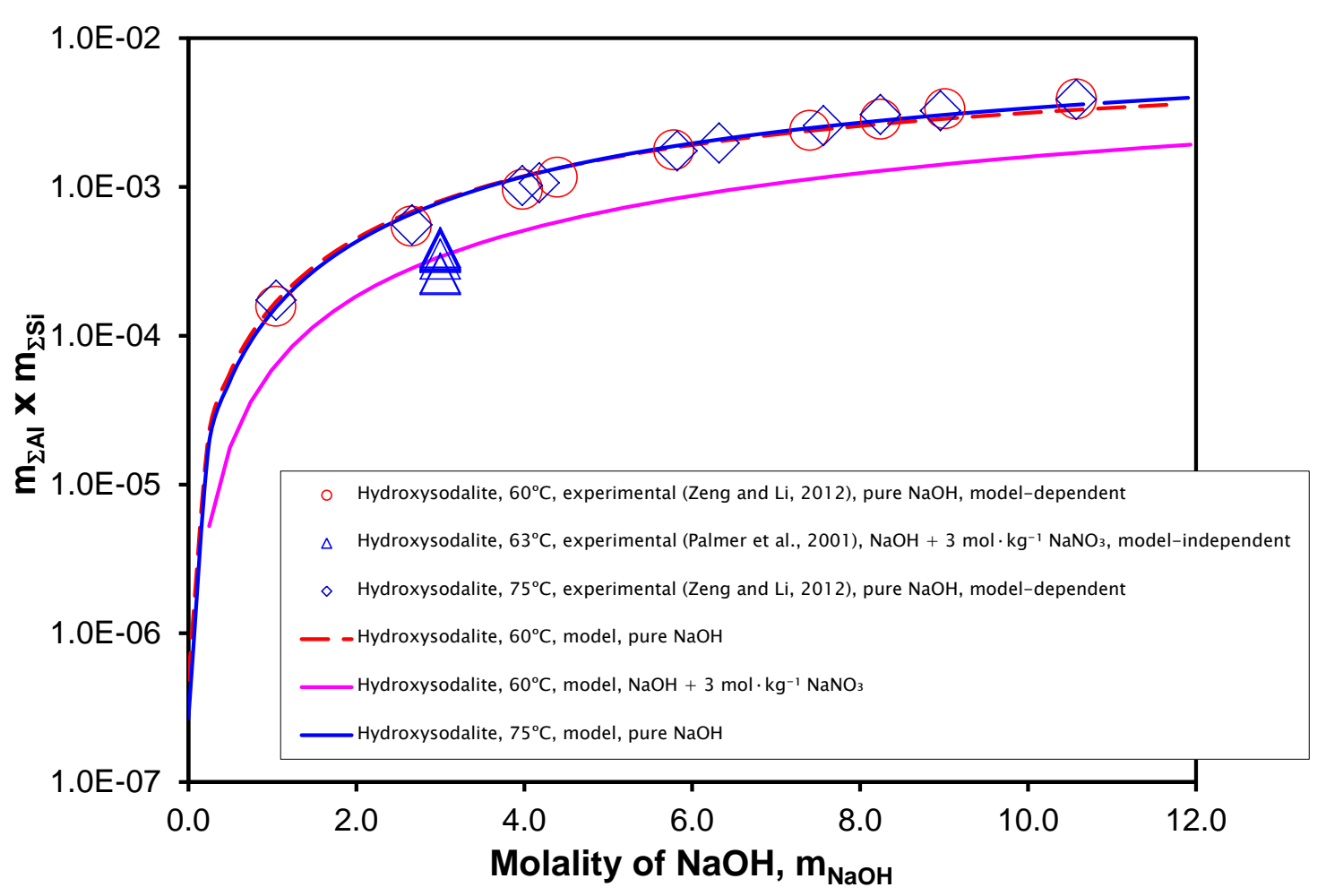

Figure 2 


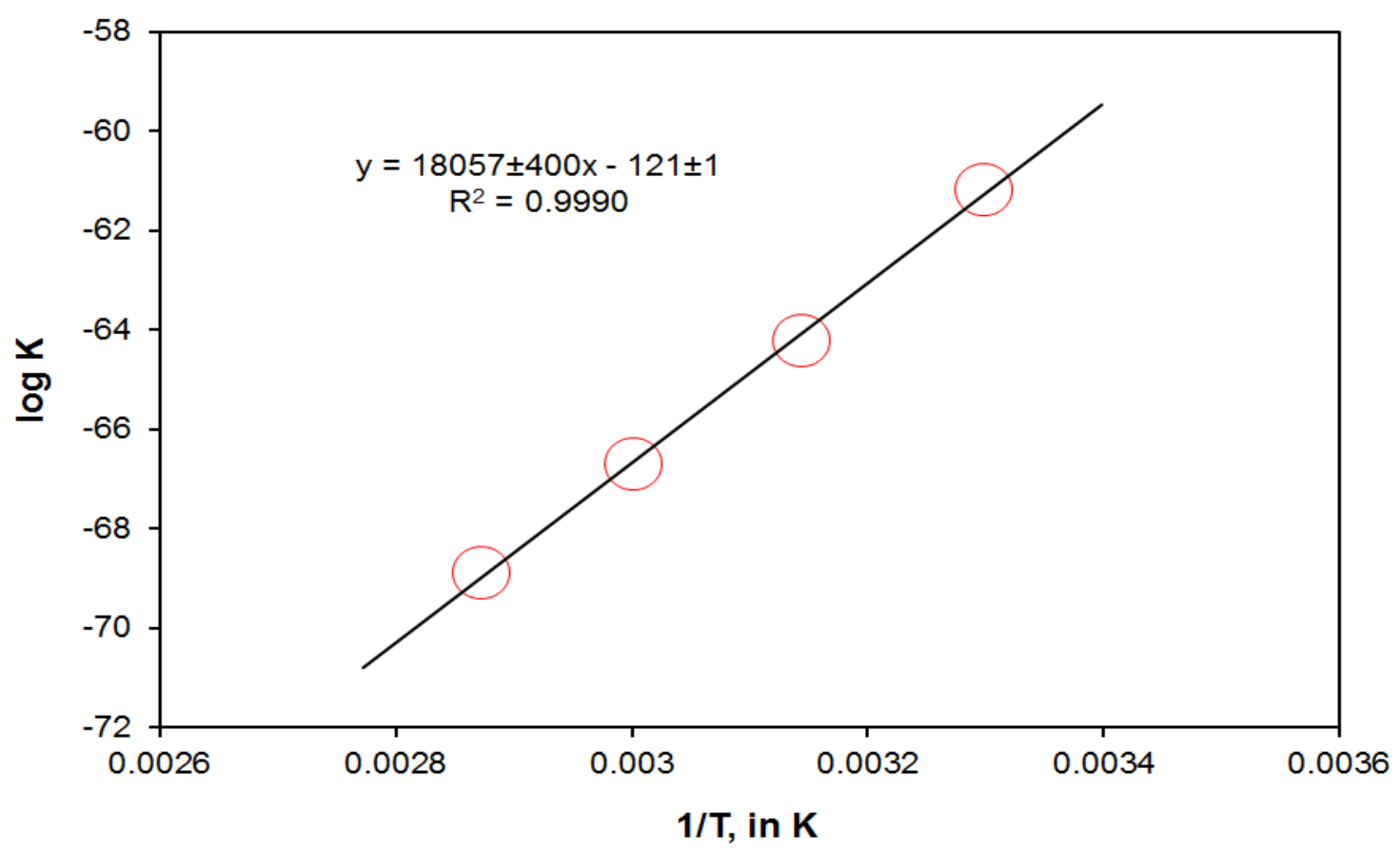

Figure 3

554 


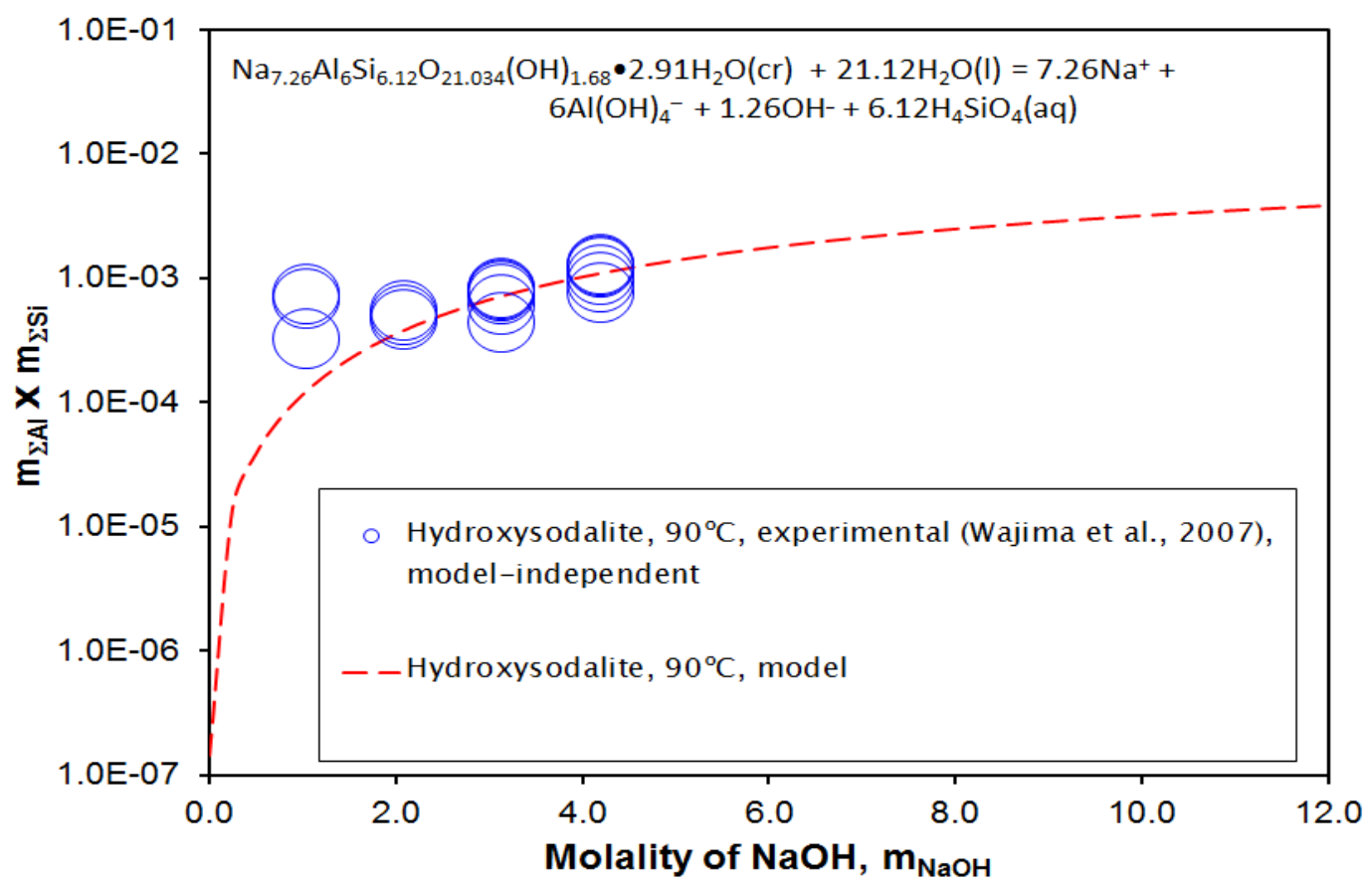

555

556

557

558

559

Figure 4 


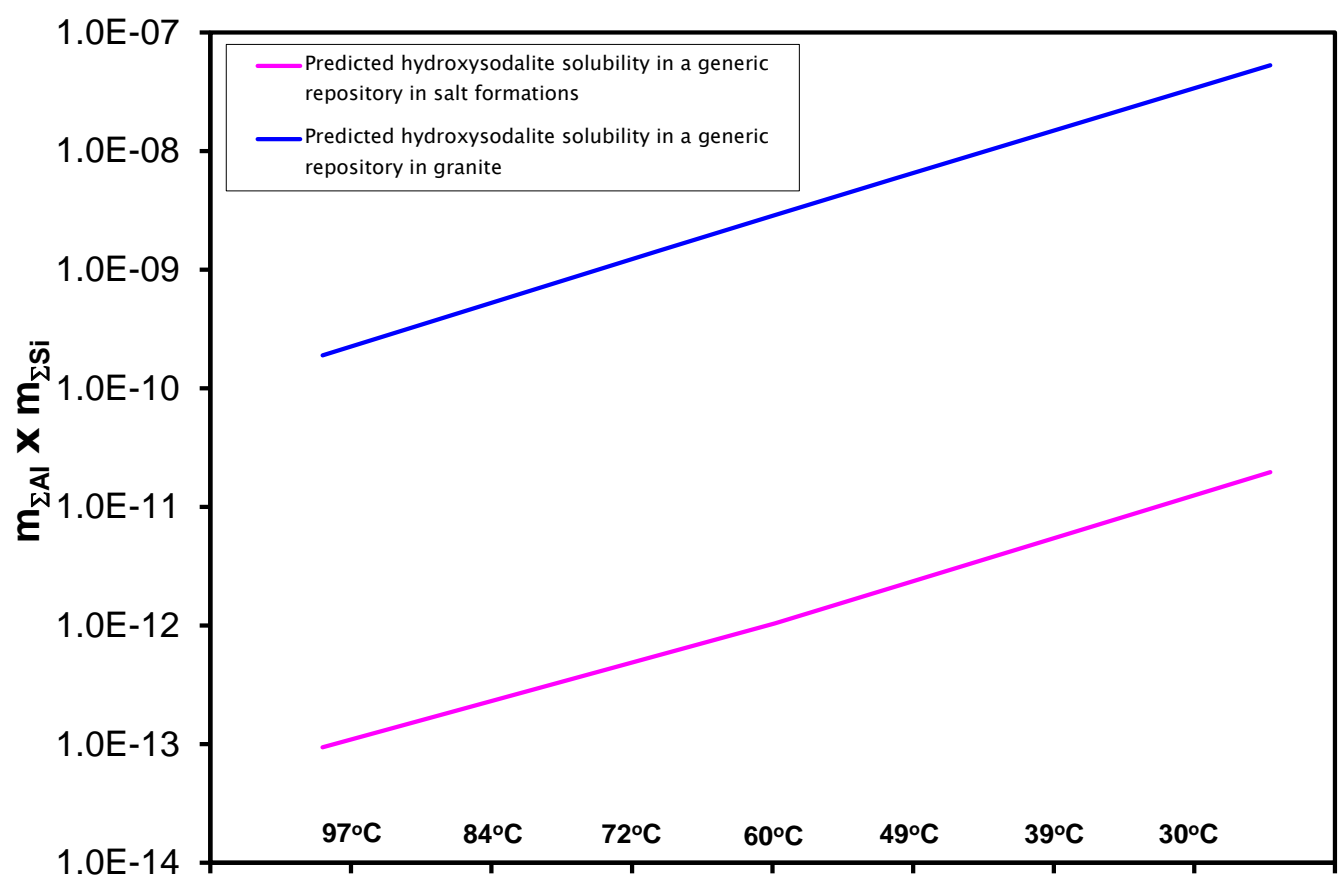

Figure 5

565

566 